\title{
Identifikasi Bakteri Gram Negatif dari Sputum Penderita Infeksi Saluran Pernapasan Akut di Rumah Sakit Dustira Kota Cimahi
}

\author{
Murleni Dorawati ${ }^{1)}, *$ Iis Herawati ${ }^{1)}$, Prima Nanda Fauziah ${ }^{2)}$ \\ ${ }^{1}$ Teknologi Laboratorium Medis, Sekolah Tinggi Ilmu Kesehatan Jenderal Achmad Yani Cimahi \\ ${ }^{2}$ Prodi Analis Kesehatan, Fakultas Kesehatan, Universitas Mohammad Husni Thamrin, Jakarta \\ *Correspodence author: Iis Herawati, iis.herawati73@yahoo.com, Cimahi, Indonesia
}

\begin{abstract}
Abstrak
Infeksi saluran pernapasan akut (ISPA) diklasifikasikan menjadi infeksi saluran pernapasan atas dan bawah. Infeksi saluran pernapasan atas dan bawah merupakan penyakit yang umum terjadi di masyarakat. Infeksi ini disebabkan oleh masuknya mikroorganisme berupa bakteri yang belum diketahui sebagai penyebab infeksi yang kemudian dapat berkembang menjadi infeksi yang disebabkan oleh bakteri Gram-positif dan bakteri Gram-negatif. Adanya bakteri penyebab ISPA diperlukan uji diagnostik menggunakan sputum. Bervariasinya mengenai bakteri yang ditemukan pada sputum, maka digunakan sampel sputum yang merupakan sampel representatif untuk mengetahui penyebab infeksi. Penelitian ini bertujuan untuk mengetahui keberadaan spesies bakteri Gram-negatif dari sputum penderita ISPA di Rumah Sakit Dustira Kota Cimahi. Metode penelitian ini menggunakan metode deskriptif melalui penelitian kultur sputum yang di tanam pada media MacConkey Agar (MCA), pewarnaan Gram mikroskopis dan uji biokimia metode IMVIC penderita ISPA periode Februari-Maret 2017. Hasil penelitian menunjukkan ditemukan bakteri Gram negatif dari 15 sampel sputum penderita ISPA terdapat spesies bakteri dengan persentase Klebsiella pneumoniae 13,3 \%, Pseudomonas aeruginosa 26,6 \% Enterobacter aerogenes 13,3\%, dan Proteus mirabilis 13,3 \%. Disarankan penegakkan diagnosis lebih diperhatikan agar lebih akurat mengenai salah satu penyebab infeksi dan para klinisi dapat menentukan terapi antibiontik selanjutnya agar pengobatan pada pasien lebih efektif dan efisien.
\end{abstract}

Kata kunci : : Infeksi saluran pernapasan akut, sputum, bakteri Gram negatif.

\begin{abstract}
Acute respiratory tract infections (ARI) are classified as upper and lower respiratory tract infections. Upper and lower respiratory tract infections are a common disease in the community. This infection is caused by the entry of mikroorganisme in the form of bacteria that have not been known as a cause of infection which can then develop into infections caused by Gram-positive bacteria and Gram-negative bacteria. The presence of bacteria that cause the ARI required diagnostic tets using sputum. Variations on bacteria found in sputum, then used samples of sputum which is a representative sample to determine the cause of infection. This study aims to determine the presence of Gram-negative bacterial species from sputum of patients with ARI at Dustira Hospital, Cimahi City. This research method using descriptive method through sputum culture research which is planted on media MacConkey Agar (MCA), Microscopic Gram staining and biochemical test of IMVIC method of ARI during February-March 2017. The results showed that Gram negative bacteria from 15 samples of sputum of patients with ARI were bacterial species with percentage of Klebsiella pneumoniae 13.3\%, Pseudomonas aeruginosa 26.6\% Enterobacter aerogenes $13.3 \%$, and Proteus mirabilis $13.3 \%$. Suggested diagnosis is more concerned to be more accurate as one of the causes of infection and clinicians can determine future antibodytics so that treatment of patients is more effective and efficient.
\end{abstract}

Keywords $\quad:$ Acute respiratory tract infection, sputum, Gram-negative bacteria

Open Journal System (OJS): journal.thamrin.ac.id 


\section{PENDAHULUAN}

Sakit merupakan gangguan psikososial yang dirasakan seseorang, berbeda dengan penyakit yang menyerang langsung pada organ tubuh berdasarkan diagnosis yang dilakukan oleh Dokter (Notosiswoyo dan Supardi, 2005). Penyakit infeksi masih merupakan penyakit utama beberapa negara berkembang, termasuk Indonesia. Jenis penyakit infeksi di Indonesia yang banyak diderita oleh masyarakat adalah infeksi saluran pernapasan akut (ISPA) baik infeksi saluran pernapasan atas atau bagian bawah (WHO, 2007), penyakit ini memiliki angka kejadian yang tinggi terurtama pada anak balita. Kenyataannya bahwa hingga saat ini dari tahun ke tahun angka morbiditas dan mortalitas akibat ISPA masih tinggi, ISPA mengakibatkan sekitar 20\%-30\% kematian pada anak balita (Depkes RI, 2000).

ISPA merupakan proses infeksi akut yang berlangsung selama 14 hari, dan disebabkan oleh mikoorganisme yang menyerang salah satu bagian atau lebih dari saluran napas, mulai dari hidung (saluran napas atas) hingga alveoli (saluran bawah), termasuk jaringan-jaringannya, seperti sinus, rongga telinga tengah, dan pleura. Gejala awal yang timbul biasanya berupa batuk pilek, dan kemudian diikuti dengan napas cepat dan sesak napas. Pada tingkat yang lebih berat terjadi kesukaran bernapas, tidak dapat minum, kejang dan kesadaran menurun, dan meninggal bila tidak diobati (Syair, 2009). Berdasarkan lokasi infeksi, ISPA diklasifikasikan menjadi infeksi saluran napas atas akut (ISNAA) atau Acute Upper Respiratory Infection (AURI) dan infeksi saluran napas bawah akut (ISNBA) atau Acute Lower Respiratory Infection (ALRI). AURI meliputi Nasofaringitis, Faringotonsilitis, sinusitis, dan Otitis Media. ALRI meliputi Epiglotitis, Laringitis, Laringotrakeitis, Bronkitis, Bronkiolitis, Influenza, dan Pneumonia (Sarathy, 2006).

Pemberian resep antibiotik yang berlebihan seringkali dijumpai pada penderita ISPA, meskipun sebagian besar penyebab penyakit ini adalah virus. Hal ini terjadi karena ekspektasi yang berlebihan para klinisi terhadap antibiotika terutama untuk mencegah infeksi sekunder yang disebabkan oleh bakteri, yang sebetulnya tidak bisa dicegah oleh antibiotik. Dampak dari semua ini adalah meningkatnya resistensi bakteri maupun peningkatan efek samping yang tidak diinginkan. Seperti diketahui ISPA yang tidak ditangani dengan tuntas dapat berkembang menjadi penyakit infeksi saluran napas yg lebih berat (Serviyanti dkk., 2012). 
Ada banyak kesalahan informasi yang berkenaan dengan infeksi saluran pernapasan akut sehingga menimbulkan beberapa masalah penting. Pertama sebagian ISPA tidak diperhatikan, akibatnya penderita mendapatkan pengobatan yang tidak diperlukan dan dengan antibiotik menambah biaya pengobatan. Kedua sering terlupakan bahwa faringitis dan tonsillitis akut adalah infeksi saluran pernapasan akut yang paling penting dan membutuhkan antibiotik yang memadai. Ketiga dokter sering tidak memperhatikan antara ISPA karena virus atau karena bakteri. Oleh karena itu perlu dilakukan pemeriksaan lebih lanjut untuk mengetahui penyebab ISPA. Sampel pemeriksaan yang dapat digunakan untuk pemeriksaan penyebab ISPA adalah sampel sputum (Fauziah dkk., 2015).

Sputum adalah lendir yang disebut juga dahak. Sputum berbeda dengan sputum yang bercampur dengan air liur. Cairan sputum lebih kental dan tidak terdapat gelembung busa di atasnya sedangkan cairan sputum yang bercampur air liur encer dan terdapat gelembung busa di atasnya (Hudoyo, 2009). Bervariasinya mengenai bakteri yang ditemukan pada kultur sputum, pemeriksaan sputum berfungsi untuk menegakkan diagnosis, uji diagnostik diperlukan untuk menanggulangi suatu bakteri yang secara keliru dinyatakan sebagai penyebab infeksi (Fauziah dkk., 2015).

Bakteri penyebab ISPA diklasifikasikan menjadi 2 kelompok, yaitu bakteri Gram-positif dan bakteri Gram-negatif. Perbedaan-perbedaan relatif antar kedua bakteri tersebut yaitu perbedaan ciri-ciri strukur dinding selnya. Berbagai bakteri penyebab ISPA adalah Streptococcus pneumoniae, Haemophilus influenzae, Staphylococcus sp, Klebsiella pneumoniae, Mycoplasma pneumoniae, Branhamella, Pseudomonas, Escherichia, dan Proteus (Altiner dkk., 2009). Bervariasinya hasil penelitian mengenai bakteri yang ditemukan, bakteri Gram-positif lebih banyak ditemukan tetapi terkadang bakteri golongan Gram-negatif bisa ditemukan lebih banyak dibandingkan bakteri Gram-positif. Oleh karena itu peneliti tertarik untuk meneliti spesies bakteri Gram-negatif dari sputum penderita ISPA di Rumah Sakit Dutira Kota Cimahi.

\section{METODE PENELITIAN}

Metode penelitian yang digunakan adalah metode deskriptif dengan melakukan identifikasi bakteri Gram-negatif dari sputum penderita infeksi saluran pernapasan akut (ISPA) 
di Rumah Sakit Dustira Kota Cimahi. Sampel pada penelitian ini adalah penderita ISPA berumur 5-65 tahun dengan kriteria diagnosis Nasofaringitis, Faringotonsilitis, Sinusitis, Otitis Media, Epiglotitis, Laringitis, Laringotrakeitis, Bronkitis, Bronkiolitis, Influenza, dan Pneumonia. Adapun bahan pemeriksaan adalah sputum.

\section{HASIL DAN PEMBAHASAN}

Pada penelitian ini diperoleh 15 sampel sputum dari pasien infeksi saluran pernapasan akut (ISPA) di Rumah Sakit Dustira Kota Cimahi selama periode Februari-Maret 2017. Keseluruhan sampel tersebut diuji melalui penanaman pada media MacConkey Agar (MCA). Hasil penanaman pada MCA menunjukkan adanya pertumbuhan bakteri pada 13 sampel (86,6 $\%$ dari total sampel) sedangkan 2 sampel (13\% dari total sampel) tidak menunjukkan adanya pertumbuhan bakteri.

Tiga belas sampel yang menunjukkan pertumbuhan pada media MCA kemudian dilanjutkan dengan identifikasi koloni menggunakan pewarnaan Gram. Hasil identifikasi dari 13 sampel diperoleh 15 koloni yang tumbuh, dengan rincian 8 sampel terdiri dari 10 koloni yang merupakan spesies bakteri Gram negatif basil (5 koloni Gram negatif basil laktosa fermenter dan 5 koloni Gram negatif basil non laktosa fermenter), 4 koloni bakteri Gram positif kokus laktosa fermenter, dan 1 koloni Yeast. Namun pada penelitian ini dilakukan identifikasi lanjutan hanya untuk kelompok koloni yang diduga bakteri Gram negatif saja. Dari 8 sampel yang tumbuh diperoleh 10 koloni bakteri Gram negatif. Kemudian 10 koloni bakteri Gram negatif ini dilakukan identifikasi lanjutan menggunakan metode uji biokimia IMVIC. Hasil dari uji biokimia IMVIC didapatkan hasil penelitian bakteri Gram negatif. Adapun hasil identifikasi bakteri Gram negatif seperti pada Tabel 1. 
Tabel 1. Hasil identifikasi bakteri Gram negatif

\begin{tabular}{lllll}
\hline No & $\begin{array}{l}\text { Nomor } \\
\text { sampel }\end{array}$ & $\begin{array}{l}\text { Spesies Begatif } \\
\text { Negateri Gram }\end{array}$ & \% Identik * & \% dari total sampel \\
\hline 1 & Sp 3 & Pseudomonas aeruginosa & $90 \%$ & $\geq 80 \%$ \\
2 & Sp 4 & Klebsiella pneumoniae & $97 \% * *$ & $\geq 80 \%$ \\
3 & Sp 7 & Enterobacter aerogenes & $81 \%$ & $\geq 80 \%$ \\
4 & Sp 9-a & Proteus mirabilis & $81 \%$ & $\geq 80 \%$ \\
5 & Sp 9-b & Pseudomonas aeruginosa & $81 \%$ & $\geq 80 \%$ \\
6 & Sp 10-a & Enterobacter aerogenes & $81 \%$ & $\geq 80 \%$ \\
7 & Sp 10-b & Pseudomonas aeruginosa & $81 \%$ & $\geq 80 \%$ \\
8 & Sp 12 & Klebsiella pneumoniae & $72 \%$ & $\leq 80 \%$ \\
9 & Sp 13 & Pseudomonas aeruginosa & $81 \%$ & $\geq 80 \%$ \\
10 & Sp 14 & Proteus mirabilis & $81 \%$ & $\geq 80 \%$ \\
& & &
\end{tabular}

\section{Keterangan :}

* Setelah dibandingkan dengan tabel hasil biokimia buku koneman , E, W (et al).1992. Color Atlas and Tevt Book of Diagnostic Microbiology. J.B Lippincott Company, Phidelphia (Winn dkk, 2006) ** Menentukan spesies menggunakan API test.

Sp: Sputum

Pertumbuhan koloni dari 8 sampel ini didapatkan hasil pertumbuhan 10 koloni bakteri Gram negatif yang bersifat 5 koloni laktosa fermenter dan 5 koloni yang bersifat non laktosa fermenter. Menurut Winn dkk (2006), laktosa adalah satu-satunya sumber karbohidrat. Bakteri laktosa fermenter menghasilkan koloni yang berwarna merah, karena konversi pewarna indikator neutral red (merah di bawah $\mathrm{pH}$ 6,8) dan produksi asam campuran sedangkan koloni bakteri non laktosa fermenter tumbuh dengan koloni tidak berwarna atau transparan. Adanya perbedaan koloni bakteri yang bersifat laktosa fermenter dan non laktosa fermenter karena disebabkan perbedaan bakteri dalam memfermentasikan bakteri sebagai sumber karbohidratnya.

Hasil identifikasi bakteri Gram negatif dari sputum penderita ISPA didapatkan spesies bakteri tersangka yaitu Klebsiella pneumoniae sebanyak 2 sampel (13,3 \%) Pseudomonas aeruginosa sebanyak 4 sampel (26,6 \%), Enterobacter aerogenes sebanyak 2 sampel (13,3\%) dan Proteus mirabilis sebanyak 2 sampel atau 13,3\%. Bakteri ini merupakan bakteri Gram negatif (Enterobacteriaceae) yang berbentuk basil sehingga dapat diketahui keberadaan spesies bakteri tersangka sebagai salah satu faktor penyebabnya. Hasil identifikasi didapatkan melalui pengujian yang dilakukan yaitu isolasi bakteri dengan menggunakan media MCA, pewarnaan 
Gram mikroskopis dengan ciri berbentuk batang, susunan satu-satu dua-dua, berwarna merah dengan sifat Gram negatif dan uji biokimia metode IMVIC (MR, VP, SIM, TSIA, SC dan urease).

Menurut Winn dkk (2006) spesies bakteri ISPA seperti Streptococcus pneumoniae, Staphylococcus aureus, Haemophilus influenza, Klebsiella Pneumoniae, Pseudomonas aeruginosa, Proteus spp, Mycobacterium spp dan Enterobacteriaceae lainnya merupakan spesies bakteri yang berpotensi sebagai agen penyebab ISPA. Pada penelitian ini karena hanya dibatasi identifikasi bakteri Gram negatif saja, spesies bakteri yang didapat dari penelitian ini yaitu Pseudomonas aerugiosa, Klebsiella pneumoniae, Enterobacter aerogenes dan Proteus mirabilis merupakan bakteri yang termasuk kelompok bakteri Gram negatif yang patogen penyebab ISPA. ISPA merupakan penyakit infeksi di Indonesia yang banyak diderita oleh masyarakat dapat disebabkan oleh mikroorganisme berupa bakteri, virus, maupun rikettsia.

Empat bakteri yang ditemukan pada penelitian ini merupakan bakteri Enterobacteriaceae yang salah satu habitatnya berada di saluran pernapasan sebagai resiko terjadiya infeksi. Resiko timbulnya ISPA terutama meningkat pada usia lanjut dan sistem kekebalan tubuh yang menurun. Selain itu, infeksi ini dapat disebabkan oleh infeksi nosokomial, yang mengalami penyebaran dan dapat menyebabkan ISPA, karena bakteri memproduksi toksin-toksin yang menyerang jaringan dan merusak sel inang yang rentan. Berdasarkan penelitian sebelumnya terdapat perbedaan hasil spesies bakteri tersangka penyebab ISPA. Pada penelitian Servianty dkk (2013) di Puskesmas Bahu yang mendapatkan hasil Klebsiella pneumoniae, Enterobacter aerogenes sebanyak 3 sampel atau $10 \%$, Escherichia coli, Pseudomonas aeroginosa, Klebsiella oxytolea, proteus stuartii sebanyak 1 sampel atau 3,3 \%. Sedangkan penelitian yang dilakukan Manggopa dkk (2016) di Poliklinik Paru RSUP Prof. Dr. R. D. Kandou Manado menemukan Enterobacter chloacae 1 sampel (5\%), Proteus alcalifaciens 1 sampel (5\%), Yersinia pestis 1 sampel (5\%), Enterobacter agglomerans 2 sampel (10\%), Serratia marcescens 1 sampel (5\%), Serratia rubidaea 1 sampel (5\%), Serratia liquefaciens 1 sampel (5\%).

Adanya bakteri Gram negatif pada ISPA yaitu karena bervariasinya mengenai bakteri yang ditemukan pada kultur sputum yang secara keliru dinyatakan sebagai penyebab infeksi (Shulman dan Stanford, 1994). Oleh karena itu, berdasarkan responnya terhadap pewarnaan Gram, bakteri penyebab ISPA umum di jumpai pada infeksi yang disebabkan oleh bakteri Gram positif dan Gram negatif. Sehingga, bakteri Gram negatif pada ISPA dapat ditemukan dan Open Journal System (OJS): journal.thamrin.ac.id 
Kadang-kadang bakteri Gram negatif bisa lebih banyak ditemukan dibanding Gram positif. Sehingga peneliti bertujuan untuk mengetahui keberadaan spesies bakteri Gram negatif dari sputum penderita ISPA. Namun, spesies bakteri penyebab infeksi setiap lokasi atau daerah berbeda-beda sehingga memberikan hasil yang bervariasi juga.

\section{SIMPULAN}

Ditemukan spesies bakteri Klebsiella pneumoniae, Pseudomonas aeruginosa, Enterobacter aerogenes, dan Proteus mirabilis dari sputum penderita ISPA di Rumah Sakit Dustira Kota Cimahi.

\section{REFERENSI}

Altiner A, Wilm S, Daubener W, Bormann C, Pentzenk M, Abholz H (2009). Sputum Colour for Diangnosis of a Bacterial Infection in Patient with Acute Cough. Scandinavian journal of primary health care. 1-4.

Biomerieux (2015). Upper and Lower Respiratory Tract Infection Samples. GCS-TM 00392015/03/20.

Capuccino G James. Sherman Natalie (2013). Microbiology A Laboratory Manual Eigthth Edition. USA: Pearson Education Inc: 75-76.

Departemen Kesehatan Republik Indonesia. (2011). Pedoman penanggulangan nasional TBC. Jakarta: Depkes RI.

Depkes RI. (2000). Pernapasan Akut ISPA Pada Balita. Jakarta.

Fauziah, P.N., Nurhajati, J., Chrysanti. (2015). Daya Antibakteri Filtrat Asam Laktat dan Bakteriosin Lactobacillus bulgaricus KS1 dalam Menghambat Pertumbuhan Klebsiella pneumoniae Strain ATCC 700603, CT1538, dan S941. Majalah Kedokteran Bandung. 47(1):35-41.

Gillespie, Stephen dan Kathleen Bamford. (2007). At a Glance Mikrobiologi Medis dan Infeksi Edisi Ketiga. Jakarta: Erlangga.

Hendro S Husodo. (2016). Pikiran Rakyat. Bandung Raya 
Hudoyo, A. (2009). Penerapan Strategi DOTS bagi Penderita TB, Dalam Simposium dan Semiloka TB Terintegrasi. Jakarta: RSUP Persahabatan.

Jawetz, Melnick and Adelberg's Mikrobiologi Kedokteran. (2004). Buku 1. Jakarta: Salemba Medika.

Kementerian Kesehatan (2012). Direktorat Bina Pelayanan Penunjang Medik dan Sarana Kesehatan. Pedoman Teknis Bangunan Rumah Sakit Instalasi Sterilisasi Sentral (CSSD). Jakarta : Kemenkes RI : 4.

Winn.C., Washington, Alten, D., Stephen at al. (2006). Koneman's Color Atlas and Textbook of Diagnosis Microbiology Shift Edition. Philadelphia Lippincott Williams \& Wilkins: $219 \& 221-226$.

Mairusnita. (2007). Karakteristik Penderita Infeksi Saluran Pernafasan Atas (ISPA) pada Balita yang Berobat ke Badan Pelayanan Kesehatan Rumah Sakit Umum Daerah (BPKRSUD) Kota Langsa Tahun 2006. Skripsi FKM USU Medan.

Manggopa, Soelionga, Homenta. (2016). Pola Bakteri Aerob pada Sputum Penderita Infeksi Saluran Pernapasan Akut. Jurnal e-Biomedik (eBm), Volume 4, Nomor 1, Januari-Juni.

Muttaqin, Arif. (2008). Buku Ajar Asuhan Keperawatan Klien dengan Gangguan Sistem Pernapasan. Jakarta: Salemba Medika.

Notosiswoyo, M., Martomijoyo, R., dan Supardi, S. (2005). Pengetahuan Sikap dan Perilaku Ibu Bayi/Anak Balita Serta Persepsi Masyarakat Dalam Kaitannya Dengan Penyakit ISPA Dan Pneumonia Di Indramayu Tahun 2001. Buletin Penelitian Kesehatan Vol 31. No. 2. Jakarta.

Sarathy, Partha. (2006). Acute Respiratory Infection in Children. Calcutta

Servianty, Soeliongan, kountul. (2012). Pola Bakteri dari Sputum Penderita Infeksi Saluran Pernapasan. Jurnal e-Biomedik (e-BM).

Shulman ST. (1994). Evaluation of penicillins, cephaloposrins, and macrolides for therapy streptococcal pharyngitis. Pediatrics.

Syair, Abdul. (2009). Faktor Resiko Kejadian Infeksi Saluran Pernpasan Akut (ISPA) pada Balita. Diakses pada tanggal 17 Maret 2012.

Tambayong Jan. (2000). Patofisiologi Untuk Perawatan. EGC; Jakarta: Penerbit buku kedokteran EGC. 